\title{
STUDI KELEMBAGAAN PERDAGANGAN SINGKONG DI KECAMATAN GUMUKMAS, KABUPATEN JEMBER
}

\author{
M. Abd. Nasir \\ Fakultas Ekonomi dan Bisnis Universitas Jember \\ abd.nasir@unej.ac.id \\ Adhitya Wardhono \\ Fakultas Ekonomi dan Bisnis Universitas Jember \\ adhitya.wardhono@unej.ac.id
}

\begin{abstract}
Cassava is one of the commodities in the agricultural sector that has the opportunity to be cultivated and marketed on a larger scale. However, the threatwere found that involved cassava trading institutions so the cassava distribution channel was also constrained. This study aims to (1) identify institutional patterns manage cassava farming, namely related stakeholder relations patterns, related rules and transaction costs in managing cassava farming; (2) implement and evaluate the business development model and the cassava farming business institutions. The method used is quantitative and qualitative in the form of existing data and tabulation of perceptual data through in-depth interview techniques. The analytical techniques used are quantitative descriptive, qualitative approaches and Value Chain Analysis. Institutional phenomena are also examined in the cassava commodity trade chain, namely social capital, and transaction costs. The results showed that the cassava trading chain in Gumukmas District involved 6 economic actors, namely (1) pure farmers; (2) industrial farmers; (3) Traders, (4) small industries; (5) large industries; (6) and consumers. The institutional trade in cassava is not intervened by government policies or farmer groups. The Institutions produced strong social capital that can decreasedthe transaction costs.
\end{abstract}

Keywords: Value Chain, institutional, Cassava Farmer Business

\begin{abstract}
Abstrak: Singkong merupakan salah satu komoditas di sektor pertanian yang memiliki peluang untuk dibudidayakan dan dipasarkan dalam skala yang lebih besar. Namun, ditemukan hambatan yang melibatkan kelembagaan perdagangan singkong sehingga alur pendistribusian singkong mempunyai hambatan. Penelitian ini bertujuan untuk (1) mengidentifikasi pola kelembagaan dalam pengelolaan usaha tani singkong yaitu pola hubungan stakeholder terkait, aturan terkait dan biaya transaksi dalam pengelolaan usaha tani singkong; (2) melakukan implementasi dan evaluasi terhadap model pengembangan usaha dan kelembagaan usaha tani singkong. Metode yang digunakan adalah kuantitatif dan kualitatif berupa existing data dan tabulasi data persepsi melalui teknik in depth interview. Teknik analisis yang digunakan adalah deskriptif kuantitatif, pendekatan kualitatif dan Analisis Rantai Nilai (Value Chain Analysis). Fenomena kelembagaan turut dikaji dalam rantai perdagangan komoditas singkong yaitu modal sosial dan biaya transaksi. Hasil penelitian menunjukan bahwa rantai perdagangan singkong di Kecamatan Gumukmas melibatkan 6 pelaku ekonomi yaitu (1) petani murni; (2) petani industri; (3) Pedagang, (4) industri kecil; (5) industri besar; (6) konsumen akhir. Kelembagaan perdagangan singkong tidak diintervensi oleh kebijakan pemerintah maupun kelompok tani. Kelembagaan menghasilkan modal sosial yang kuat yang dapat meminimalisir keberadaan biaya transaksi.
\end{abstract}

Kata Kunci: Rantai Nilai, kelembagaan, Usaha Tani Singkong 


\section{Pendahuluan}

Kabupaten Jember memiliki berbagai komoditas potensial di sektor pertanian, salah satunya adalah singkong (Tanuwijaya, 2013). Hal tersebut tampak dari produktivitas dan jumlah produksi singkong di Kabupaten Jember yang cukup tinggi. Berdasarkan data Badan Pusat Statistik Kabupaten Jember diketahui bahwa produktivitas dan jumlah produksi singkong pada tahun 2012 berturut-turut sebesar $174,40 \mathrm{kw} / \mathrm{ha}$ dan $478.030 \mathrm{kw}$ dengan total luas panen sebesar 2.471 ha (Badan Pusat Statistik, 2013). Sebaran potensi singkong di Kabupaten Jember cukup merata, yakni terdapat pada 28 kecamatan dari 31 kecamatan pada kabupaten tersebut, antara lain: kecamatan Kencong, Gumukmas, Puger, Wuluhan, Ambulu, Tempurejo, Silo, Mayang, Mumbulsari, Ajung, Rambipuji, Balung, Semboro, Jombang, Sumberbaru, Tanggul, Bangsalsari, Panti, Sukorambi, Arjasa, Pakusari, Kalisat, Ledokombo, Sumberjambe, Sukowono, Jelbuk, Kaliwates, Sumbersari dan Patrang (Badan Pusat Statistik, 2013; Badan Pusat Statistik Kabupaten Jember, 2013).

Sejak lama singkong dianggap sebagai tanaman sub sistem bagi petani kecil, namun singkong memiliki peluang untuk dibudidaya dalam skala besar untuk menghasilkan bahan baku pengolahan industri (Minot, 1999; Okorie, 2012). Singkong dewasa ini merupakan bahan dasar dari berbagai jenis produk seperti, berbagai olahan makanan, tepung, pakan, alkohol, bahan kertas dan tekstil, pemanis dan produk-produk lain yang dapat terurai secara hayati (Agriculture Research Council, 2017). Jenis-jenis produk turunan singkong di atas merupakan peluang pengembangan pasar. Rantai pasokan produk singkong cenderung dimulai dengan unit produksi berskala kecil, diikuti oleh unit pengolahan produk berskala kecil melalui proses pengeringan dan penggilingan singkong. Seiring dengan bergeraknya produk melalui rantai pasokan tersebut, kegiatan seperti pemasaran, pengolahan dan pengemasan dilakukan oleh beberapa unit berskalalebihbesar yang kemudian mendistribusikan produk akhir ke konsumen dalam jumlahbesar. Rantai pasok produk singkong berstruktur seperti jam pasir yang berbeda dari rantai pasokan komoditas pertanian mapan lainnya. Keberadaan rantai pasok jam pasir ini menunjukkan bahwa pertumbuhan dan perkembangan pasar produk singkong dapat menguntungkan sejumlah besar petani miskin yang berada di lahan miskin maupun pada unit pengolahan lokal (Pingmuanglek et al., 2017). Tantangan dalam pengembangan industri singkong dari hulu sampai ke hilir adalah bagaimana 
membekali petani dengan pengetahuan dan alat yang dibutuhkan untuk menghasilkan produk yang memenuhi persyaratanpertumbuhan pasar (Wibowoet al., 2015). Kedua, bagaimana menghadapi pertumbuhan pasar yang mengarah pada rantai pasokan yang berubah (Agriculture Research Council, 2017). Dengan demikian, perubahan pada struktur rantai pasokan harus dievaluasi saat menilai peluang pasar.

Kelembagaan merupakan faktor penting yang menggerakkan kinerja dari pengelolaansumberdayapertanian (Lin dan Jeffrey, 1995; Furubotn dan Ritcher, 2005). Kelembagaanmenghasilkanperaturanatau kebijakan yang merupakan aturan main (rule of game) dalam pengelolaan sumberdaya (Zucker, 1987; Indrayanti, 2013).Masing-masing pihak memiliki peran dan kegiatan yang berbeda-beda dalam mengelola sumberdaya pertanian.Konflik antar petani serta tingginya biaya transaksi yang cenderung tidak efisien merupakanpermasalahan yang dihadapi oleh pelaku usaha tani di sektor pertanian (Dutilly-Diane et al.,2003). Besarnya biaya transaksi yang ditentukan sepihak oleh pembeli tidak diketahui oleh petani mengakibatkan terjadinya imperfect market (Lanzona dan Evenson, 1997; Nigel dan Janvry, 2000). Dengan demikian, harga yang diterima petani lebih murah dibanding apabila petani menjual sendiri. Implikasinya biaya transaksi adalah masalah yang mempengaruhi keputusan industri dalam produksi, alokasi tenaga kerja maupun keputusan konsumsi. Peningkatan biaya transaksi menyebabkan terjadinya kegagalan pasar (market failure).Tujuan dari penelitian ini adalah untuk mengkaji kelembagaan perdagangan singkong dari hulu sampai ke hilir dengan menggunakan analisis rantai nilai (value chain analysis). Pemilihan analisis tersebut karena dapat digunakan untuk menganalisa alur distribusi perdagangan singkong.

\section{Metodologi}

Penelitian ini merupakan jenis penelitian Action Research karena mencakup dua tahapan aspek yaitu aspek studi dasar penelitian mencakup penguatan kelembagaan usaha (Tuan, 2012). Sementara aspek tindakan atau pengayaan mencakup pengembangan dan pendampingan usaha sertakelembagaan (Ostrom, 1985; North, 1990). Selain itu juga diperlukan adanya tahapan evaluasi atau monitoring. Penentuan lokasi penelitian dilakukan secara dengan sengaja atau purposive sampling yaitu di Kecamatan Gumukmas, Kabupaten Jember. Penentuan sasaran kegiatan atau responden adalah para petani sebagai produsen sampai 
konsumen akhir sertastakeholder terkait dengan jumlah sampel sebanyak 60 responden.

Metode yang digunakan adalah kuantitatif dan kualitatif berupa existing data dan tabulasi data persepsi melalui teknik in-depth interview(Bardhan, 1989). Teknik analisis yang digunakanadalahdeskriptifkuantitatif, pendekatankualitatifdan analisis rantai nilai (value chain).Penelitian kualitatif dimaksudkan sebagai jenis penelitian yang tidak diperoleh melalui prosedur statistik. Metode kualitatif dapat digunakan untuk mengungkap dan memahami sesuatu di balik fenomena. Value Chain Analyisis, merupakan alat untuk memahami rantai nilai yang membentuk suatu produk.Value Chain mengidentifikasikan dan menghubungkan berbagai aktivitas strategik di industri (Hansen, Mowen, 2000). Tujuan dari analisis value-chain adalah untuk mengidentifikasi tahap-tahap value chain di mana industri dapat meningkatkan value untuk pelanggan atau untuk menurunkan biaya. Penurunan biaya atau peningkatan nilai tambah (Value added) dapat membuat industri lebih kompetitif (Coase, 1960; Bardhan, 1962).

Peningkatan nilai tambah (Value added) atau penurunan biaya dapat dicapai dengan cara mencari prestasi yang lebih baik yang berkaitan dengan supplier, dengan mempermudah distribusi produk, outsourcing (yaitu mencari komponen atau jasa yang disediakan oleh industri lain), dan dengan cara mengidentifikasi bidangbidang dimana industri tidak kompetitif (Becker, 1962). Selanjutnya dalam kaitanya antara value chain dengan value coalitions, Weiler et al, (2003), menyatakan bahwa Value Chain Analysis dan Value Coalitions Analysis, adalah pendekatan yang didesain untuk sebuah industri yang diidentifikasi melalui nilai ekonomi dari konsumen, yaitu didasarkan pada; Pertama, work activity based; merupakan pola pemrosesan yang didasarkan pada suatu set aktivitas pendukung dari sebuah arus kerja (workflow). Dan Kedua, Functional Organization; yaitu didasarkan pada fungsi organisasi keseluruhan dari top level sampai down level suatu organisasi yang ada dan terlibat di dalamnya (Parson, 1965; Ostrom, 1999).

\section{Hasil dan Pembahasan}

Rantai perdagangan singkong dan produk derivatifnya di Kecamatan Gumukmas ditunjukan oleh Gambar 1. Rantai nilai perdagangan singkong melibatkan 6 pelaku ekonomi yaitu: a) Petani murni; b) Petani industri; c) Pedagang; d) Industri kecil; e) Industri besar; f) konsumen. Keenam pelaku ekonomi tersebut saling terintegrasi satu sama lain yang membentuk pola kelembagaan. 
Petani secara fungsional dalam kegiatan produksi dibagi menjadi dua jenis, yaitu petani murni dan petani industri. Petani murni adalah petani yang memproduksi singkong dan langsung menjualnya tanpa mengolah hasil panennya. Hasil panen singkong dari petani murni dijual kepada pedagang petani industri (Swedberg, 1991). Singkong di Kecamatan Gumukmas pada dasarnya bukan merupakan komoditas utama. Kondisi geografis Kecamatan Gumukmas yang landai dan dekat dengan pantai selatan kurang cocok digunakan untuk menanam singkong. Menurut hasil wawancara dengan Sekretaris Desa Mayangan dan Kepala Dusun, pada tahun 2014 terdapat hubungan kemitraan dengan swasta untuk penanaman singkong secara besar-besaran di dekat area pantai. Namun petani mengalami gagal panen karena kualitas hasil pertanian yang buruk diakibatkan tanah berpasir sehingga daging singkong menjadi terlalu empuk dan tidak layak masuk pabrik. Para petani dibantu oleh perangkat desa kemudian mencoba untuk menjual hasil panen singkong tersebut ke pasar Klakah, Kabupaten Lumajang namun juga ditolak dengan alasan yang sama yaitu kualitas yang buruk sehingga tidak akan laku di pasar. Hal tersebut yang juga mengakibatkan sebagian besar petani singkong di daerah tersebut mengalami kerugian besar dan memutuskan untuk tidak menanam singkong.

Petani singkong yang tetap bertahan menanam singkong adalah petani yang memiliki lahan ladang dan cenderung cukup jauh dari saluran irigasi. Alasan menanam singkong di lahan tersebut adalah karena tanaman singkong relatif lebih mudah beradaptasi di lahan kering dan tadah hujan dibandingkan tanaman produktif lain seperti jagung dan cabai. Pola tanam petani singkong ladang di daerah dataran tinggi adalah menanam singkong selama setahun, dimulai pada pertengahan musim hujan dan pada saat bulan ramadan dan dipanen pada saat bulan ramadan juga. Tujuannya adalah untuk menjual hasil panen singkong ke industri pembuatan tape dan diprediksi harga singkong pasca panen lebih menguntungkan pada saat mendekati bulan ramadan dan idul fitri.

Petani industri adalah petani yang menanam singkong sebagai bahan baku industrinya. Industri tersebut merupakan industri makanan olahan singkong yaitu keripik singkong dan tape singkong. Alasan utama dari industri untuk menanam sendiri bahan baku singkongnya terletak pada ketidakstabilan stok dan harga singkong di pasar dan juga untuk mengurangi biaya pembelian bahan baku. Industri 
ini termasuk dalam kategori industri skala rumah tangga yang hanya dibantu oleh beberapa pekerja tidak tetap.

Petani Industri yang mengolah keripik mendapatkan stok bahan baku tidak hanya dari hasil pertaniannya sendiri, tetapi juga melalui petani murni dan pedagang. Umumnya, pembelian singkong sebagai bahan baku dilakukan pada saat stok bahan baku dari ladangnya tidak cukup untuk memenuhi target produksi. Harga beli singkong bahan baku rata-rata sebesar Rp 1.500/kg di tingkat petani, dan sebesar Rp 2.200/kg di tingkat pedagang. selanjutnya, hasil produksi keripik dikemas dalam bungkus plastik kecil dan dijual seharga Rp1.000/bungkus yang dipasarkan ke kios-kios kecil. Harga rata-rata Rp 19.000/kg dengan marjin keuntungan sebesar $30 \% / \mathrm{kg}$.

Petani industri yang mengolah singkong menjadi tape memiliki pola tanam yang lebih lama. Penanaman dan pemanenan singkong dilakukan pada saat musim hujan bulan ramadan karena produksi tape dilakukan dibulan tersebut. Permintaan tape singkong pada bulan ramadan dan idul fitri mengalami peningkatan yang signifikan. Penjualan hasil produksi tape singkong bekerjasama dengan kios-kios pusat oleh-oleh Kabupaten Jember. 


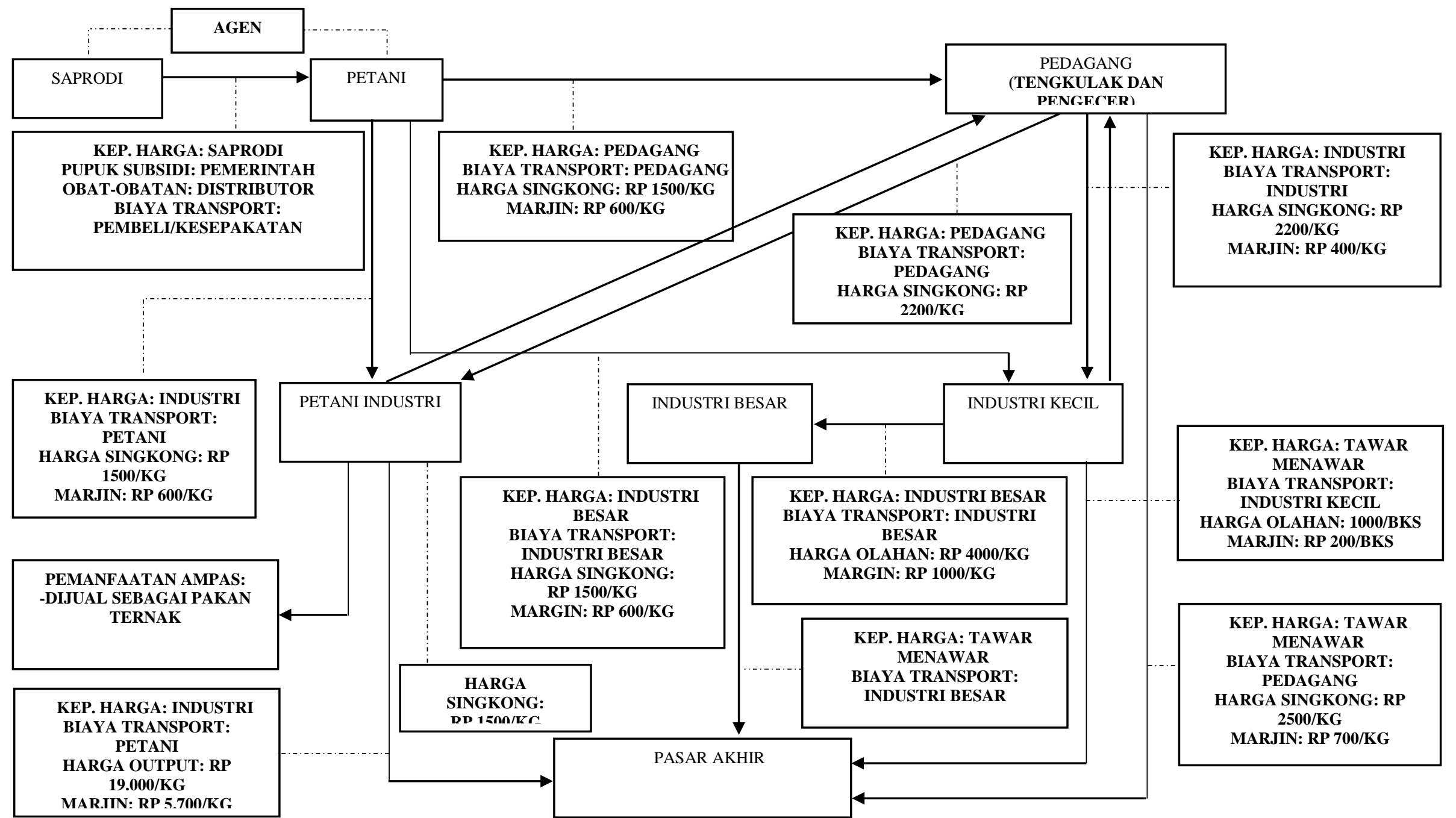

Gambar 1. Rantai Perdagangan Komoditas Singkong Kecamatan Gumukmas

Sumber: Data Primer, diolah, 2017 
Harga jual tape singkong adalah Rp8000/bungkus dengan berat rata-rata 7ons/bungkus. Nilai tambah yang diperoleh cukup besar jika dibandingkan dengan harga singkong/kg di tingkat petani. Namun demikian, meskipun permintaan tape meningkat pada saat bulan ramadan dan idul fitri tetapi terdapat masalah yang juga dialami oleh petani industri tape, yaitu tingkat keawetan tape yang hanya sebentar sehingga kerugian petani industri tape terjadi saat pengembalian tape oleh kios pusat oleh-oleh.

Menurut penuturan responden, besarnya permintaan tape juga diimbangi oleh produksi tape dan juga masuknya tape dari Kabupaten lain terutama Bondowoso sebagai produsen tape terbesar. Salah seorang responden petani industri tape menuturkan bahwa pada ramadan tahun 2017 lalu, laba yang diperoleh dari penjualan tape hanya berkisar sebesar Rp 2.000.000 untuk luas ladang sebesar $0,25 \mathrm{Ha}$. Kecilnya laba yang diperoleh dikarenakan pengembalian tape karena tidak laku dijual sampai tanggal kadaluarsanya.

Perdagangan hasil panen singkong oleh petani murni dilakukan dengan beberapa pelaku ekonomi lain yaitu petani industri, pedagang, dan industri kecil. Harga singkong di tingkat petani murni pada dasarnya berfluktuasi pada kisaran $\mathrm{Rp}$ 700-2500/kg. Harga dalam penelitian ini berdasarkan hasil wawancara menunjukan harga rata-rata yaitu sebesar Rp1.500/kg. Sistem pembayaran yang berlaku di Kecamatan Gumukmas adalah pembayaran tunai saat terjadi transaksi antara penjual yaitu petani dan pembeli yaitu pedagang, petani industri, dan industri kecil.

Saprodi adalah distributor bibit, pupuk dan pestisida yang dibutuhkan dalam mengelola lahan pertanian. Saprodi tersebar di daerah-daerah pertanian dan berkontribusi dalam pertanian di suatu daerah. Saprodi dalam rantai perdagangan singkong di Kecamatan Gumukmas adalah sebagai penyedia pupuk dan pestisida. Hasil wawancara kepada beberapa saprodi di Kecamatan Gumukmas menunjukan bahwa saprodi di Gumukmas tidak menyediakan bibit singkong untuk petani karena faktor permintaan yang rendah. Umumnya, petani singkong membudidayakan sendiri bibit singkong dari tanaman yang telah dipanen pada periode sebelumnya. Saprodi lebih berperan kepada distribusi pupuk dan pestisida yang dibutuhkan oleh petani singkong. Terkait dengan subsidi pupuk, menurut saprodi tidak ada subsidi yang secara khusus diberikan kepada komoditas singkong. Pemberian subsidi tidak dikhususkan pada komoditas tertentu, yang terpenting petani tergabung sebagai anggota salah satu kelompok tani. 
Pedagang secara spesifik dibagi menjadi dua yaitu tengkulak dan pengecer, namun dalam penelitian ini keduanya dihimpun ke dalam satu kelompok agen ekonomi yaitu sebagai pedagang. Pedagang merupakan pembeli singkong mentah dari petani murni dan sebagai penjual singkong pada industri dan pasar. Pedagang berperan sebagai distributor singkong ke pelaku-pelaku ekonomi di pasar singkong Kecamatan Gumukmas. Pedagang memasok singkong dari petani tidak hanya di Kecamatan Gumukmas, tetapi juga kecamatan sekitarnya. Harga singkong bergerak sesuai dengan kuantitas stok singkong di pasar. Jika jumlah singkong berkurang atau permintaan produk olahan singkong mengalami kenaikan harga, maka harga singkong akan meningkat sampai kisaran Rp2.000-2500/kg. Namun jika yang terjadi sebaliknya, maka harga singkong di tingkat petani akan mengalami penurunan bahkan sampai Rp 700/kg sehingga petani mengalami kerugian pada tingkat harga tersebut. Pedagang kemudian menjual singkong yang belum diolah ke pasar akhir, industri kecil ataupun ke petani industri.

Industri tape memperoleh singkong sebagai bahan baku dari petani dan pedagang singkong. Harga beli singkong pada tingkat petani lebih murah dibanding pada tingkat pedagang yang mematok harga rata-rata sebesar Rp 2.200/kg. Namun demikian, industri tape lebih memilih membeli singkong dari pedagang karena stabilnya pasokan singkong. Penjualan ke kios-kios pusat oleh-oleh Jember dipatok dengan harga yang sama seperti petani industri tape.

Permasalahan utama yang dirasakan belakangan ini oleh industri tape adalah menurunnya stok singkong di pasar. Menurut penuturan salah satu responden, penurunan tersebut dikarenakan adanya alih fungsi lahan pertanian dan juga karena adanya peralihan komoditas yang ditanam oleh petani. Petani singkong di Kecamatan Gumukmas mengalami peralihan ke tanaman cabai dan semangka. Penurunan tersebut pada akhirnya dapat meningkatkan harga singkong pada tingkat petani.

Industri kecil adalah industri pengolahan dengan jumlah karyawan kurang dari 20 orang. Industri kecil yang terdapat di Kecamatan Gumukmas berbadan usaha koperasi yang memproduksi chips Mocaf untuk kemudian di jual ke Pabrik besar yang memproduksi tepung mocaf. Koperasi tersebut bekerjasama dengan petani lokal dalam bentuk kemitraan, dan koperasi menjadi distributor bibit singkong dan juga pembeli tunggal singkong dari petani yang menjadi mitra. 
Tujuan utama dibentuknya koperasi tersebut adalah meningkatkan kesadaran petani akan nilai ekonomis dari singkong, serta meningkatkan kesejahteraan hidup para petani yang bermitra dengan koperasi. Selain kesejahteraan petani, keberadaan pabrik pembuat chip mocaf juga dapat membuka lapangan kerja baru yang mampu menampung pekerja dari sekitar lokasi pabrik. Permasalahan yang timbul adalah harga fluktuasi harga singkong yang mengakibatkan harga chip mocaf juga terpengaruhi. Pada saat penelitian ini dilakukan, pembina koperasi menyatakan bahwa saat ini pabrik chip mocaf tidak sedang berproduksi karena harga beli yang dipatok oleh pabrik tepung mocaf sangat murah. Menurut penuturan pembina koperasi tersebut, turunnya harga chip mocaf dikarenakan adanya impor singkong yang mengganggu keseimbangan harga lokal. Pada akhirnya, penurunan harga tersebut berdampak pada penurunan harga singkong di tingkat petani. Petani pada akhirnya tidak berani memanen singkong karena harga jualnya yang dinilai merugikan bagi petani.

Industri besar yang berkaitan dengan komoditas singkong di Kecamatan Gumukmas adalah Pabrik pengolahan tepung mocaf di Kabupaten Solo. Nama tepung mocaf merupakan singkatan dari Modified Cassava Flour atau tepung singkong modifikasi. Tepung mocaf juga disebut dengan tepung motekap. Tepung mocaf merupakan tepung modifikasi yang ditemukan oleh Achmad Subagio dan merupakan yang pertama di Dunia. Tepung mocaf adalah tepung hasil olahan singkong yang diproses dengan memodifikasi sel singkong melalui fermentasi yang melibatkan mikroba (bakteri asam laktat). Tepung mocaf dipromosikan sebagai subtitusi atau komplementer tepung terigu dan dapat menghemat biaya penggunaan tepung terigu.

Industri besar yang berkaitan dengan koperasi yang memproduksi chip mocaf adalah perusahaan produsen tepung mocaf yaitu PT. Bangkit Cassava Mandiri (BCM) yang merupakan anak perusahaan dari Tiga Pilar Group. PT BCM memiliki pabrik pengolahan chip mocaf di Kabupaten trenggalek dan Karanganyar. PT BCM menjalin hubungan kerjasama dengan dengan pola kemitraan antara inti (yaitu PT BCM) dan plasma (yang disebut dengan cluster). Cluster adalah unit-unit usaha dengan kapasitas produksi yang relatif lebih kecil dibandingkan dengan PT BCM dengan tujuan untuk memproduksi chip mocaf sebagai produk setengah jadi untuk memproduksi tepung mocaf. Dalam penelitian ini, keterbatasan untuk mewawancarai PT BCM sebagai salah satu unit dalam rantai perdagangan adalah 
dikarenakan letak responden yang berada di luar lingkup wilayah penelitian yaitu di Kecamatan Gumukmas. Oleh karena itu, tidak dapat diketahui nilai tambah dari tepung mocaf yang diproduksi.

Gambar 2 menjelaskan alur perdagangan singkong dari hulu yaitu petani singkong sampai pada tingkat hilir yaitu konsumen akhir yang mengkonsumsi berbagai jenis produk olahan singkong. Penyedia input merupakan pelaku ekonomi awal yang menyediakan berbagai macam kebutuhan pertanian agar petani dapat menghasilkan hasil pertanian yang optimal. Secara umum petani membeli bibit, pupuk dan pestisida ke penyedia input yaitu saprodi dan atau kelompok tani.

Penyedia input dalam kelembagaan komoditas singkong (berdasarkan hasil wawancara dengan responden) tidak berkontribusi besar. Proses penanaman singkong sampai panen relatif lebih sederhana dibandingkan dengan komoditas lain (semisal padi, jagung dan Singkong) sehingga petani tidak harus memberikan perhatian lebih terhadap tanaman singkongnya. Dengan demikian, konsumsi pupuk dan pestisida relatif sedikit. Peran saprodi bagi petani singkong di Kecamatan Gumukmas juga rendah. Saprodi tidak menyediakan bibit singkong karena permintaan yang sangat rendah dan petani lebih cenderung untuk menggunakan batang tanaman singkong yang telah dipanen sebagai bibit untuk masa tanam periode selanjutnya. Petani singkong juga jarang menggunakan pestisida karena singkong merupakan tanaman yang cukup kuat terhadap hama dan penyakit yang umum menyerang tanaman.

Hama yang paling berbahaya bagi tanaman singkong di Kecamatan Gumukmas adalah tikus dan ulat tanah. Tikus merupakan hama yang susah untuk dibasmi dan membutuhkan koordinasi para petani dalam pembasmiannya. Menurut penuturan salah seorang petani, pembasmian hama tikus tidak dapat menggunakan racun yang dilakukan hanya di satu bidang sawah saja, karena jika demikian tikus akan semakin merusak lahan pertanian lainnya karena mereka bergerak dalam kelompok yang cukup besar. Salah satu cara yang dapat dilakukan oleh petani adalah dengan membudidayakan musuh alami tikus dalam rantai makanan, yaitu burung hantu. Pelestarian keberadaan burung hantu telah dilakukan di kecamatan lain di Jember.

Dinas Pertanian Jember sebagai pelaksana kebijakan pemerintah pusat memiliki wewenang dan kewajiban untuk melindungi sektor pertanian dengan cara menyediakan berbagai layanan yang dapat mendorong produktivitas petani 
(Krisnabudiet al., 2013; Wardhonoet al., 2013). Pada saat penelitian ini dilakukan, Dinas Pertanian Kabupaten Jember bekerja sama dengan tingkat Provinsi mengadakan Forum Temu Lapang Petani di Kecamatan Kencong yang juga dihadiri oleh beberapa petani singkong dari Kecamatan Gumukmas. Pada Forum tersebut, salah satu fasilitas yang dapat digunakan oleh petani dalam rangka penyediaan input pertanian singkong adalah sertifikasi bibit. Sertikasi bibit merupakan suatu layanan yang memungkinkan petani singkong untuk memperbaiki kualitas bibit yang mereka olah dari batang singkong yang telah dipanen pada periode sebelumnya (Halif, 2013). Petani dapat membawa batang singkong yang akan dijadikan bibit ke Dinas Pertanian Kabupaten Jember untuk disertifikasi dengan biaya Rp 100.000,untuk satu orang petani, dan jika mengatasnamakan kelompok tani, biayanya dapat ditekan sampai Rp 50.000,- untuk masing-masing anggota kelompok tani.

Bagian kedua dari gambar di atas adalah petani singkong. Petani singkong di Kecamatan Gumukmas relatif lebih sedikit dibandingkan dengan komoditas lain. Sebagian besar petani di Gumukmas lebih memilih untuk menanam padi, jagung, dan semangka dibandingkan dengan menanam singkong. Petani mengatakan bahwa pilihan komoditas selain singkong untuk dibudidayakan adalah karena prospek komoditas selain singkong lebih bagus. Selain itu, perkembangan tanaman singkong juga sangat dipengaruhi oleh cuaca yang tidak menentu. Pada saat musim kemarau, singkong dapat bertahan dengan asupan air yang minim, namun hasil panen tidak maksimal. Di sisi lain, pada saat musim penghujan umbi singkong dapat membusuk karena kadar air dan kelembaban tanah yang tinggi. Alasan lainnya adalah harga jual di tingkat petani yang rendah dan berfluktuatif, sedangkan masa tanamnya membutuhkan waktu setidaknya 7-8 bulan sampai tanaman dapat dipanen. 


\begin{tabular}{|c|c|c|c|c|c|}
\hline $\begin{array}{l}\text { PENYEDIA } \\
\text { INPUT } \\
\end{array}$ & PETANI & $\begin{array}{c}\text { PETANI } \\
\text { INDUSTRI }\end{array}$ & PEDAGANG & PENGUSAHA & PEMASARAN \\
\hline $\begin{array}{l}\text { PENYEDIA } \\
\text { BAHAN } \\
\text { PENDUKUNG } \\
\text { TANAMAN } \\
\text { SINGKONG }\end{array}$ & $\begin{array}{l}\text { PENANAMAN } \\
\text { PEMELIHARAAN } \\
\text { PEMANENAN }\end{array}$ & $\begin{array}{l}\text { PEMBELIAN } \\
\text { SINGKONG } \\
\text { PENAKSIRAN } \\
\text { HARGA } \\
\text { PENGUKURAN } \\
\text { KUALITAS }\end{array}$ & $\begin{array}{l}\text { PEMBELIAN } \\
\text { SINGKONG } \\
\text { PENAKSIRAN } \\
\text { HARGA } \\
\text { PENGUKURAN } \\
\text { KUALITAS }\end{array}$ & $\begin{array}{l}\text { PEMBELIAN } \\
\text { SINGKONG } \\
\text { PEMROSESAN } \\
\text { SINGKONG } \\
\text { PENAKSIRAN } \\
\text { HARGA }\end{array}$ & $\mathrm{LC}$ \\
\hline \multirow{3}{*}{$\begin{array}{c}\text { BELUM TERSEDIANYA } \\
\text { JENIS BIBIT SINGKONG } \\
\text { YANG TAHAN } \\
\text { TERHADAP ANOMALI } \\
\text { IKLIM. } \\
\text { HARGA PUPUK DAN } \\
\text { PESTISIDA MENINGKAT } \\
\text { DISTRIBUSI SAPRODI } \\
\text { YANG TIDAK } \\
\text { TERPANTAU }\end{array}$} & \multirow{3}{*}{$\begin{array}{l}\text { ANOMALI IKLIM. } \\
\text { HARGA SINGKONG } \\
\text { YANG FLUKTUATIF } \\
\text { MINIMNYA BANTUAN } \\
\text { DARI PEMERINTAH } \\
\text { (TEKNIS DAN NON } \\
\text { TEKNIS) DAN } \\
\text { PEMODALAN }\end{array}$} & \multirow{3}{*}{$\begin{array}{c}\text { PERMAINAN HARGA } \\
\text { JUAL DENGAN } \\
\text { KUALITAS } \\
\text { SINGKONG YANG } \\
\text { TIDAK STANDAR } \\
\text { BERSAING DENGAN } \\
\text { SINGKONG IMPOR }\end{array}$} & \multirow{3}{*}{$\begin{array}{c}\text { HARGA SINGKONG } \\
\text { ANTAR PETANI, } \\
\text { PENGEPUL, } \\
\text { PEDAGANG KECIL } \\
\text { YANG TIDAK } \\
\text { TRANSPARAN DAN } \\
\text { STANDAR } \\
\text { MINIMNYA PASOKAN } \\
\text { SAAT MUSIM } \\
\text { PENGHUJAN } \\
\text { BERSAING DENGAN } \\
\text { SINGKONG IMPOR } \\
\end{array}$} & \multirow{3}{*}{$\begin{array}{c}\text { HARGA SINGKONG } \\
\text { ANTAR PETANI, } \\
\text { PENGEPUL, } \\
\text { PEDAGANG KECIL } \\
\text { YANG TIDAK } \\
\text { TRANSPARAN DAN } \\
\text { STANDAR } \\
\text { MINIMNYA PASOKAN } \\
\text { SAAT MUSIM } \\
\text { PENGHUJAN } \\
\text { BERSAING DENGAN } \\
\text { SINGKONG IMPOR } \\
\end{array}$} & $\begin{array}{l}\text { PEMODALAN UNTUK } \\
\text { BIAYA STOK } \\
\text { SINGKONG }\end{array}$ \\
\hline & & & & & \\
\hline & & & & & $\begin{array}{l}\text { PEMENUHAN } \\
\text { KEBUTUHAN } \\
\text { PASAR }\end{array}$ \\
\hline $\begin{array}{c}\text { PEMENUHAN } \\
\text { KEBUTUHAN PASAR }\end{array}$ & $\begin{array}{c}\text { PEMENUHAN } \\
\text { KEBUTUHAN PASAR }\end{array}$ & $\begin{array}{c}\text { MENJAMIN } \\
\text { KECEPATAN } \\
\text { TRANSAKSI } \\
\text { PERDAGANGAN } \\
\text { SUMBER } \\
\text { MATAPENCAHARIAN } \\
\text { PETANI } \\
\end{array}$ & $\begin{array}{c}\text { SUMBER } \\
\text { MATAPENCAHARIAN } \\
\text { PETANI } \\
\text { PENINGKATAN } \\
\text { KUALITAS SINGKONG }\end{array}$ & $\begin{array}{c}\text { SUMBER } \\
\text { MATAPENCAHARIAN PETANI } \\
\text { DAN PEDAGANG } \\
\text { PENINGKATAN KUALITAS } \\
\text { SINGKONG } \\
\text { PEMENUHAN KEBUTUHAN } \\
\text { PASAR }\end{array}$ & \\
\hline
\end{tabular}

Gambar 2. Skema Rantai nilai pasokan Singkong di Kecamatan Gumukmas

Sumber: Data primer, diolah, 2017 
Kebijakan pemerintah pertanian untuk komoditas singkong sangat minim menurut petani (Halif, 2013). Dinas Pertanian pun menyatakan bahwa kebijakan dan regulasi pemerintah pusat pada komoditas singkong masih relatif sedikit. Hal tersebut dikarenakan pada era Presiden Jokowidodo, kebijakan swasembada pangan pemerintah pusat terfokus pada tanaman padi, jagung, dan kedelai (PAJALE). Dampaknya, komoditas singkong terkesan kurang diperhatikan. Dinas Pertanian Kabupaten Jember dalam rangka meningkatkan kesejahteraan petani singkong sejauh ini telah melakukan berbagai kegiatan pelatihan pembudidayaan dan pengolahan pasca panen. Namun intervensi secara langsung dalam pasar singkong masih belum dilaksanakan. Imbasnya, harga jual tingkat petani mengalami fluktuasi, diikuti oleh sulitnya petani untuk mengakses pasar singkong. pada akhirnya, petani lebih memilih untuk bermitra dengan perusahaan yang mengolah produksi derivatif dari singkong.

\section{Kesimpulan}

Kesimpulan yang diperoleh dalam penelitian menunjukkan bahwa rantai perdagangan singkong di Kecamatan Gumukmas melibatkan: (a) Petani murni yang menjual langsung hasil panen singkongnya ke pelaku ekonomi lain, (b) Petani Industri yaitu industri yang memperoleh input dari menanam singkong secara mandiri dan menjual hasil produksi olahannya ke pedagang, (c) Pedagang, yaitu pelaku ekonomi yang juga berfungsi sebagai penghubung input dari petani ke industri (sebagai tengkulak) maupun konsumen akhir (sebagai pengecer), (d) Industri kecil yang membutuhkan input dari petani lalu mengolah bahan mentah tersebut kemudian memasarkannya secara langsung (ke konsumen atau industri besar) maupun melalui pengecer, (e) Industri besar tunggal yang terlibat dalam rantai perdagangan singkong adalah produsen tepung mocaf, dan (f) Konsumen akhir.

Paradigma kelembagaan yang terekam dalam penelitian ini adalah biaya transaksi dan modal sosial. Modal sosial yang dibangun dalam rantai perdagangan singkong di Kecamatan Gumukmas dan kemudahan untuk mengakses informasi harga mampu mereduksi biaya transaksi.

\section{Saran}

Minimnya peran pemerintah dalam regulasi dan kebijakan pada komoditas singkong ini, maka diperlukan sinergitas antara Dinas Pertanian, pelaku usaha, dan 
petani dalam rangka meningkatkan kesejahteraan petani singkong. Sehingga regulasi dan kebijakan dalam melakukan intervensi langsung dalam pasar singkong dapat dilaksanakan. Imbasnya, harga jual tingkat petani akan stabil, dengan akses pasar singkong yang lebih luas. Intensifikasi berbagai kegiatan pelatihan pembudidayaan dan pengolahan pasca panen singkong dapat terus dilakukan.

\section{Daftar Referensi}

Agricultural Research Council. 2017. Cassava. [serial online]. http://www.arc.agric.za/arc-iic/Pages/Cassava.aspx

Badan Pusat Statistik Indonesia. 2013. Berbagai Edisi Publikasi. [serial online]. http://www.bps.go.id.

Badan Pusat Statistik Indonesia. 2014. Berbagai Edisi Publikasi. [serial online]. http://www.bps.go.id

Badan Pusat Statistik Kabupaten Jember. 2013. Data dan Statistik Kabupaten Jember 2013. Kerjasama BadanPerencanaan Pembangunan Kabupaten Jember. Jember: Badan Pusat Staistik Kabupaten Jember dan Badan Perencanaan Pembangunan Kabupaten (BAPPEKAB) Pemerintahan Kabupaten Jember.

Bardhan P. 1989. Alternative Approaches to the Theory of Institutional in Economic Development. Dalam Pranab Bardhan. (ed). The Economic Theory of Agrarian Institutions. Oxpord : Clarendon Press

Bardhan, Pranab. 1993. Economic of Development and the Development of Economic. Journal of Economic Perspectives, Vol. 7 No. 2, Hal. 129-142.

Becker, Gary. 1962. Investment in Human Capital: A Theoretical Analysis. Journal of Political Economy, Vol. 70, Hal. 9-49.

Coase, R. H. 1960. The Problem of Social Cost. Journal of Law and Economics, Vol. 3, Hal. 1-44.

Dutilly-Diane, C., E. Sadoulet and A. de Janvry. 2003. Household Behavior Under Market Failures: How Natural Resource Management in Promotes Livestock Production in the Sahel. Department of Agricultural and Resource Economics. University of California, Berkeley.

Furubotn, Eirik G dan Richter, Rudolf. 2005. Institutions and Economic Theory. Second edition: The University of Michigan Press.

Halif. 2013. Upaya Pemerintah Kabupaten Jember dalam Perlindungan Hukum kepada Petani Singkong. Jember: Universitas Jember.

Krishnabudi, N. G., Qori'ah, Ciplis G., Wardhono, Adhitya dan Sarwedi. 2013. Agribisnis Kedelai dan Ketahanan Pangan di Kabupaten Jember: Telaah Saluran Distribusi Pemasaran dan Struktur-Perilaku Pasar. Jurnal IImu Ekonomi, Vol. 8, No. 3, Hal. 371-382. 
Lanzona, R and R.E. Evenson. 1997. The Effect of Trnsaction Costs on Labor Market Participation and Earnings: Evidence From Rural Philippine Markets. Economic Growth Center, Yale University. New Haven, Connecticut 06520-8269

Lin, Justin Yifu dan Nugent, Jeffrey B. 1995. Chapter 38 Institutions and Economic Development. Handbook of Development Economics, Vol. 3, Hal. 2301-2370. https://doi.org/10.1016/S1573-4471(05)80010-5

Minot, N. 1999. Effect of Transaction Cost on Supply Response and Marketed Surplus : Simulations Using Non-Separable Household Model. Internatioal Food Policy Researh Institute Washington, D.C.

Nigel, K., E. Sadoulet and A. De Janvry. 2000. Transaction costs and agricultural household supply response. American Journal Agricultural Economics 82(2): $245-259$.

North D.C. 1990. Institutions, Institutional change and Economic Performance. Cambridge : Cambridge University Press

Okorie, Oguejiofor Joseph. 2012. Level of Adoption of Improved CassavaVarieties And The Profitability ofCassava Production In Enugu State,Nigeria. Disertation: Department of Agricultural EconomicsUniversity of Nigeria, Nsukka

Ostrom E. 1985. Self-Government of common-pool resources. Workshop in political theory and policy analysis. Indiana University, Indiana, USA. 39 pp.

Ostrom, E. 1999: Coping with the Tragedies of the Commons, Annual Review of Political Science 2, 493-535.

Swedberg, Richard. 1991. Major Traditions of Economic Sociology. Annual Review of Sociology, Vol. 17, Hal. 251-276.

Tanuwijaya, Fanny. 2013. Kebijakan Pengelolaan Tanaman Singkong dalam Meningkatkan Kesejahteraan Petani Singkong di Kabupaten Jember. Jember: Universitas Jember.

Tuan, Nham Pong. 2012. Governance, Institutional, and Pro-Poor Analysis of Cassava Contract Farming in Quang Tri Province, Vietnam. Vietnam National University, Hanoi.

Wardhono, Adhitya, Qoria'ah, Ciplis G., Sarwedi, Krishnabudi, N. G., Prakoso, B., dan Sandy, W. T. 2013. Kajian Model dan Strategi Pengembangan Agribinis Tanaman Pangan di Kabupaten Jember. Jurnal IImu Ekonomi, Vol. 8, No. 3, Hal. 297-312.

Wibowo, Y., Purnomo, Bambang H. dan Mufidah, Icha L. 2015. Analisis Finansial Agroindustri Unggulan Berbasis Singkong di KabupatenJember. Berkala IImiahPertanian, Vol. 1, No. 1.

Zucker, Lynne G. 1987. Institutional Theories of Organization. Annual Review of Sociology, Vol. 13, Hal. 443-464. 